\title{
Empirical analysis of inbound open innovation and small and medium-sized enterprises' performance: Evidence from oil and gas industry
}

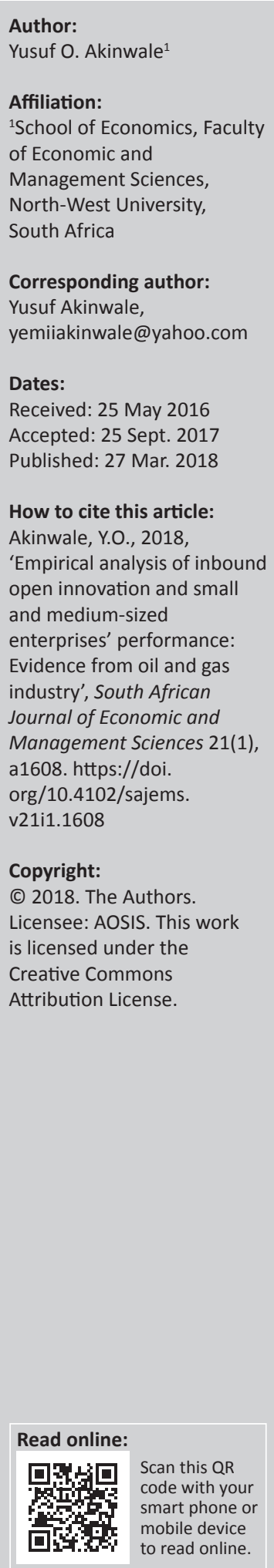

Background: This article contributes to existing literature by examining the relationship between inbound open innovation and firms' financial performance in the Nigerian oil and gas industry.

Aim: This article seeks to identify the factors of inbound open innovation and whether these factors influence the financial performance of small and medium-sized enterprises (SMEs) in the Nigerian oil and gas industry.

Setting: This article examines 150 indigenous oil and gas SMEs in the upstream subsector of the Nigerian petroleum sector through a survey, using a questionnaire, conducted in 2015.

Methods: The study applied the structural equation modelling (SEM) method. This method is used to test the relationships between the factors and to calculate the measurement errors in the hypotheses formulated.

Results: The results show that technology scouting, vertical technology collaboration (VTC) and horizontal technology collaboration (HTC) positively and significantly contribute to inbound open innovation, which are thus significant in influencing the financial performance of SMEs. The size of technical staff and research and development (R\&D) fund allocations also have a positive and significant correlation with the SMEs' financial performance. Meanwhile, the age of SMEs is negative and not significant in influencing financial performance.

Conclusion: The results suggest that inbound open innovation through scouting, HTC and VTC should therefore be encouraged among SMEs to boost their internal capabilities, which have hitherto enhanced their financial performance. The management members of each SME should continually consider collaboration with the external actors because they cannot singularly possess all the innovative skills required in the industry. Also, each firm should commit itself to allocate more funds to R\&D and at the same time should hire those who have relevant production skills and train the existing ones in their firms.

\section{Introduction}

The role played by innovation in the present competitive world cannot be undermined (Bosworth \& Collins 2003; Colombo, Pivo \& Rosi-Lamastra 2014). A firm that fails to innovate in its competitive environment will definitely be pushed out of the market (Adelowo, Akinwale \& Olaopa 2017; Akinwale et al. 2012). Therefore, innovation becomes an arrow that drives productivity in all sectors of the economy (Kim 2011). Innovation is traditionally viewed as taking place mostly within a single firm (Akinwale, Adepoju \& Olomu 2017; Chesbrough 2003b). However, it has become a vital element in today's globalised and competitive environment (Mytelka 2000). Firms which engage in innovation do not only gain competitiveness but are also able to sustain themselves for a longer period of time (Ismail et al. 2014). To remain competitive and relevant in today's modern world requires organisations to vigorously pursue innovation. Because a firm cannot operate in isolation, there is a need to relate to the external environment in which it operates. Today, the logic that supports an internally oriented and centralised approach to research and development (R\&D) has become obsolete in many sectors (Chesbrough 2003b). This creates a new logic of open innovation, which embraces external ideas and knowledge in conjunction with internal R\&D.

In the wake of these changes, the concept of open innovation has emerged, with processes that are characterised as spanning firms' boundaries (Lee et al. 2010). The basis for the idea of openness is that a single organisation cannot innovate in isolation. It has to engage with 
different types of partners to acquire ideas and resources from the external environment to stay abreast of competition and to become more profitable (Chesbrough 2003b; Laursen \& Salter 2006). This has stimulated questions about the role of openness in innovation that emphasises the permeability of firms' boundaries where ideas, resources and individuals flow in and out of organisations, as well as its impacts on firms' performance (Dahlander \& Gann 2010). Chesbrough (2003a) defined open innovation as a paradigm that assumes that firms can and should use external and internal ideas as well as internal and external paths to market, as they look to advance their technology in promoting their innovative and financial performance. It is a distributed innovation process which is based on purposively managed knowledge flows across organisational boundaries (Chesbrough \& Bogers 2014).

Because attention has shifted from the concept of closed to open innovation in the last decade, open innovation has become a widely known business strategy in many sectors of different economies, and various studies have been conducted in that regard (Ahn, Minshall \& Mortara 2015; Chesbrough 2006; Dahlander \& Gann 2010; Hippel 2005; Huizingh 2011; Laursen \& Salter 2006). However, most of the past studies concentrate on studying open innovation in large and multinational companies in developed countries and how it influences the firms' profits and performance. While some studies in the literature have established that large firms are more innovative as a result of economies of scale, human and financial capabilities, which improve their higher financial performance (Gault 2010; Waheed 2012), others suggest that smaller firms are more efficient innovators because of their flexibility in nature, which enables them to meet the need of more customers and hence improves their financial performance (Kasseeah 2013; Qian \& Li 2003). Thus, the argument of financial performance through open innovation and firms' size is inconclusive. The success of Intel, Oracle, Microsoft and many others indicates the potential advantages of open innovation in a business market and the impacts on financial performance (Chesbrough 2003a). There are limited studies on the relationship between open innovation and financial performance in small and medium-sized enterprises (Ahn et al. 2015; Kim \& Park 2010; Parida, Westerberg \& Frishammar 2012; Van de Vrande et al. 2009), and most of them are mainly conducted in the developed economies. At the time of writing this article there is a dearth of empirical research in this area in developing countries, especially in Nigeria. Although the majority of firms in developing countries, Nigeria in particular, are SMEs and are characterised by limited human and financial capabilities, their extent of adopting innovation to drive financial performance is not negligible (Adeyeye et al. 2015). The level of in-house $R \& D$ capabilities and the extent of interactions of the knowledge institutions with some SMEs in the manufacturing and service sectors may generally be inadequate and low, yet these firms continue to strive to bolster their profits through innovations (Adeyeye, Jegede
\& Akinwale 2013; Akinwale et al. 2017; Egbetokun, Adeniyi \& Siyanbola 2012; Siyanbola et al. 2012).

This study seeks to contribute to existing literature and also fill the gap relating to the relationship between open innovation and firms' financial performance in SMEs in developing countries. The main objective of this study is to examine the influence of inbound open innovation on the financial performance of SMEs in the Nigerian oil and gas industry.

\section{Open innovation in small and medium-sized enterprises and hypothesis development Open innovation in small and medium-sized
enterprises}

The construct of open innovation was first introduced by Chesbrough in 2003, and this has attracted many scholarly contributions on various phenomena that constitute open innovation, as well as its effect on industry and firms' innovative and financial performances. The impact of open innovation has considerably improved the performance of firms through an increase in market share and revenue (Ahn et al. 2015). Open innovation is the purposive inflow and outflow of knowledge to accelerate internal innovation, and expand the market for external use of innovation, respectively' (Chesbrough, Vanhaverbeke \& West 2006). This implies that with open innovation, both internal and external knowledge can find their way to commercialisation for existing or new markets by crossing a firm's boundary. Open innovation can be broadly categorised into two: inbound and outbound.

Inbound innovation is concerned with a firm leveraging on the discoveries of others, abandoning the idea of relying merely on the firm's internal R\&D (Chesbrough et al. 2006). According to Laursen and Salter (2006), openness to external sources of knowledge allows firms to feed their pipeline of ideas by expanding the pool of opportunities available to them and at the same time increasing their innovativeness. Inbound open innovation evaluates the degree to which a firm accesses available external technologies to compliment the ones it already possesses (Chesbrough \& Crowther 2006; Hung \& Chou 2013; Lichtenthaler 2009; Spithoven, Clarysse \& Knockaert 2010). This includes acquiring external knowledge, in-sourcing (or licensing-in), joint $R \& D$, mergers and acquisition or strategic alliance and end-user involvement (Hung \& Chou 2013).

On the other hand, outbound open innovation is concerned with a firm exploiting technology capabilities by leveraging on external paths of commercialisation (Chesbrough 2003a). In other word, outbound open innovation is an outward transfer of a firm's technological knowledge to outside firms to obtain monetary or non-monetary benefits (Lichtenthaler 2009). This includes 'Licensing-out' and 'spin-off' among others. Because of the nature of innovation prevalent in developing countries, this study focuses on inbound open innovation among SMEs in the Nigerian oil and gas sector. 
Small and medium-sized enterprises are usually classified according to the number of employees or assets of a firm. SMEs in Nigeria consist of employees between 10 and 199 or assets (excluding land and building) between N5 million and N500 million (National Bureau of Statistics 2015). But in a situation where there is a conflict between the number of employees and total assets of the firm, then the number of employees will take precedence. There is growing recognition of the important role Micro, Small and Medium Enterprises (MSMEs) play in economic development. SMEs play a significant role in the development of a country's rural and urban labour forces through job creation opportunities, leading to provision of desirable sustainability and innovation in the economy as a whole (Olomu et al. 2016; Small and Medium Enterprises Development Agency of Nigeria [SMEDAN] 2015). Beyond job creations, SMEs are a growthsupporting sector that bring substantial local capital formation and are responsible for driving innovation and competition in developing economies. The different levels of Governments have undertaken initiatives to promote the growth and development of MSMEs in Nigeria (SMEDAN/ NBS 2013). Majority of the Nigerian populace depends directly or indirectly on the SMEs as a means of sustenance which shows that virtually a great part of the business establishments in Nigeria is tied to SMEs. As at 2013, MSMEs contribution to the Nation's Gross Domestic Product in nominal terms stood at $48.47 \%$ and most of them are operating below optimum capacity utilisation (SMEDAN/ NBS 2013). The total number of persons employed by the MSME sector represents $84.02 \%$ of the total labour force, while over $70 \%$ of the entrepreneurs do not have patent right; hence, their intellectual property are not protected (SMEDAN 2015). The ownership structure by age showed that the age bracket of 24-50 dominates the sector, which indicates predominance of youth entrepreneurship in the country. Several efforts are on-going concurrently within the last two decades to boost this sector of the national economy, starting from the creation of an Agency solely responsible for the promotion and development of this sector (SMEDAN), implementation of the National Enterprise Development Programme, creation of the MSME national and state councils, YOUWIN and its inclusion among the recent top federal government execution priorities to drive industrialisation (The Nigerian Economic Recovery and Growth Plan 2017-2020 Report 2017). As a result of the strategic position the oil and gas sector is occupying in Nigerian economy, the activities of the SMEs in the sector cannot be undermined in employment generation, wealth creation and capability building among others.

Oil and gas sector is characterised by high capital outlay, high risk and uncertainties, high return and high level of technological innovation (Akinwale 2016). The firms in this sector tend to continuously engage in innovative activities to meet up with the technological trajectory of the sector. Because most of the indigenous firms and few of the international firms fall within the category of SMEs in Nigeria, it becomes imperative to examine the importance of open innovation in relations to financial performance among those SMEs. Some of these SMEs usually lack a full set of internal resources and capabilities to effectively develop, produce and implement their innovations (Colombo et al. 2014). Thus, SMEs strongly welcomed external collaborations to access missing innovations inputs (Van de Vrande et al. 2009). Open innovation can be a good approach in enhancing SMEs' performance. The flexibility and simple hierarchy of SMEs may give them a strong advantage in theimplementation of open innovation to generate more income (Rothwell \& Dodgson 1994; Teece 1996). Opening of SME boundaries can provide access to the necessary complimentary resources to deal with inadequate $R \& D$ capacity, as well as involving competitors, suppliers and end-users in their innovation process to develop relational capabilities (Ahn et al. 2015; Lee et al. 2010). However, it was noted that most SMEs are resource-constrained and might not be able to engage many open innovation modes at the same time. Although poor innovation capacity of SMEs might be as a result of weak financial and human resources, some of these SMEs are sometimes innovative as a result of their heterogeneous character.

Kaufmann and Tödtling (2002) in their study negate the misconception that SMEs have limited innovation. Chesbrough (2003a) already revealed that small firms continually increased their share of total industrial R\&D spending in the USA during the last two decades as they account for an average of $24 \%$ of all US industry spending in 2005 , compared to $4 \%$ in 1981, whereas the larger firms were responsible for an average of $38 \%$ of total industry R\&D spending in 2005, compared to 71\% in 1981 (National Science Foundation 2006; Van de Vrande et al. 2009). There is no doubt that larger firms are still playing a major role in innovation, but the smaller firms are increasingly giving importance to industrial $R \& D$, hence improving the industry productivity.

The oil and gas sector contributes above $90 \%$ to the Nigerian foreign exchange earnings and $72 \%$ to the government federally generated revenue in 2014 (Central Bank of Nigeria 2015). Although the proportion of contribution of the oil and gas sector to foreign exchange earnings and federally collected revenue is high, it has been declining over the years as shown in Figure 1. Despite the dominance of oil and gas in the country's foreign exchange earnings and internally generated revenue, its proportional contribution to the gross domestic product (GDP) is relatively low and at the same time declining in the last few years as shown in Figure 2. The sector is dominated by the large multinational oil and gas firms. Most of the indigenous firms in the sector are SMEs. The activities of the Nigerian oil and gas SMEs were primarily dominated by closed innovation. However, with the increasing technological complexity and the need to collaborate with those that can assist them in dealing with their inadequate R\&D capacity, Nigerian oil and gas SMEs have started adopting open innovation. Over the years, SMEs have not been adequately accommodated in the Nigerian oil 


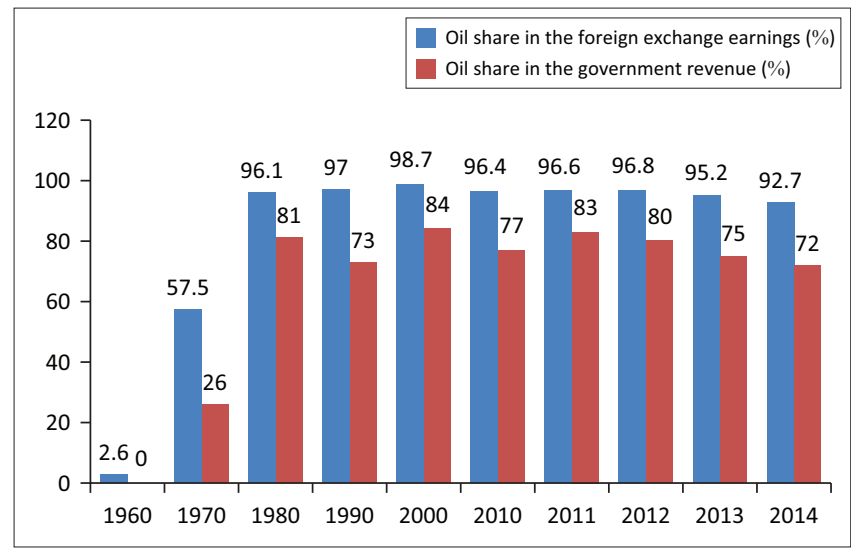

FIGURE 1: Proportion of oil sector share in Nigerian foreign exchange earnings and total federally collected revenue.

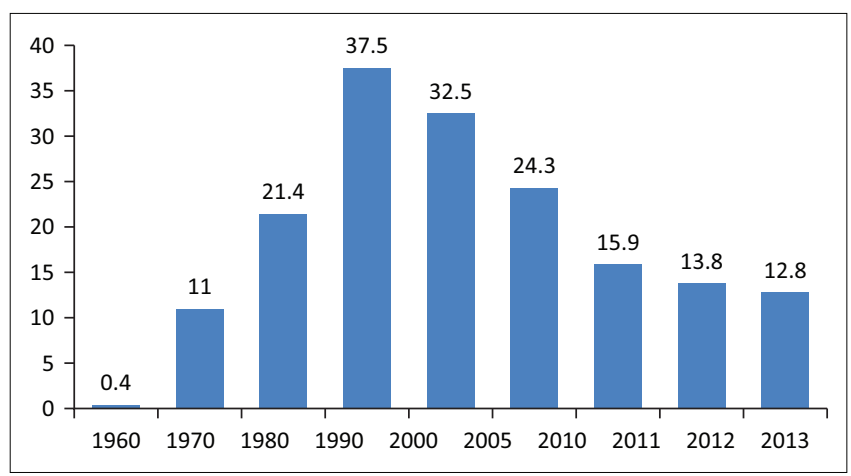

FIGURE 2: Proportion of oil sector contribution to real gross domestic product in Nigeria (\%).

and gas industry. This was attributed to the low level of local content implementation, which emanated from the lack of requisite skills, technical expertise, manpower and production capacity, and capability to compete favourably (Aigboduwa \& Oisamoje 2013; Ariweriokuma 2009). However this trend seems to be changing gradually because the Federal Government of Nigeria introduced marginal field development initiative and local content act in the oil sector (Akinwale 2016). This is expected to develop the capabilities of the SMEs in the sector and at the same time generate employment opportunities and reduce poverty in the economy.

\section{Hypothesis development}

Because the role of inbound open innovation in a firm is based on the extent and sources of acquisition of external knowledge, it becomes necessary for the firm to create welldeveloped mechanisms for accessing the value of external knowledge. This study adopts technology scouting (TS), horizontal technology collaboration (HTC) and vertical technology collaboration (VTC) as variables to acquire external knowledge as used in the work of Parida, Westerberg and Frishammar (2012) and Wang, Chang and Shen (2015). These variables were considered relevant to this study, as compared to the SMEs in the oil and gas industry. These variables are identified as the key sources of external knowledge resources for enhancing innovation, which expectedly bolster financial performance.
Technology scouting simply means searching for a new technology beyond the firm's boundary that can assist its innovative efforts. It also refers to an internal search or scanning function, which assesses the technological trends so as to detect opportunities and threats in a timely manner to reap financial gains (Bianchi et al. 2010; Parida et al. 2012). This implies that TS involves both searching for technology acquisition channels and supporting the process of innovation efforts. TS characterises an innovation process in which external actors are involved as sources for ideas, new and crucial knowledge, technical solutions and acquisitions or even discovery opportunities (Wang et al. 2015). The importance of TS includes gathering ideas, information and knowledge useful to support the firm's internal innovation process from the external environment. It therefore plays a vital role in building innovation capability and increases the financial performance of an SME. Conversely, TS may also lead to confusion for SMEs, as it generates too many potential ideas in which SMEs may lack the ability to appropriately allocate internal resources to manage them (Koput 1997). Generally, firms that search for new innovative ideas outside their boundary have potential for improved financial performance.

$\mathbf{H}^{1}$ : Technology scouting has a significant influence on the SME performance

Horizontal technology collaboration is mainly concerned with a firm collaborating with partners that are not part of the value chain of that firm. SMEs can use complimentary and advanced technologies to develop their own innovation by relying on cooperative or co-developed capabilities with multiple partners. This collaboration could be done with other firms from the same industry or another industry and/ or with competitors or non-competitors. However, collaboration with firms within the same industry and with non-competitors seems to be easier as the actors involved could all benefit from combining resources and competencies to develop innovative products which could lead to improved financial performance (Parida et al. 2012; Pittaway et al. 2004). This does not mean that collaboration with firms in other industry and competing firms could not be beneficial. Horizontal collaborations with competitors enable firms to develop and harness advanced technology. SMEs in the Nigerian oil industry could benefit from and leverage on the technology capabilities of other collaborative firms to improve their financial performance.

\section{$\mathbf{H}_{2}$ : HTC has a significant influence on SMEs' performance}

Vertical technology collaboration in this context represents collaborative relationships with present and potential customers, and end-users for an improved internal innovation process (Henkel 2006; Hippel 2005). Lukas and Ferrel (2000) opined that customers are often considered very valuable as a novel knowledge source because their specific demand may anticipate the contribution of innovation efforts. Chesbrough et al. (2006) viewed firms' VTC capability being affected by the extent to which the firm can connect with external communities in the innovation process. The 
customers help the firms to gain access to valuable resources through high-frequency interactions with the firms. Customers willingly provide information on their needs and expectations in the market. This invariably enables the producing firms to provide their customers better with services because they are able to access information and knowledge that cannot be produced within the firm. Based on the aforementioned, VTC is suggested as an important variable in inbound open innovation that can influence the SMEs' performance.

$\mathbf{H}_{3}$ : Vertical technology collaboration has a significant influence on SMEs' performance

Brunswicker and Vanhaverbeke (2014) found that not all open innovation modes are always beneficial in enhancing performance. Hung and Chou (2013) investigated the influence of external technology acquisition (i.e. inbound open innovation) and external technology exploitation (i.e. outbound open innovation) on financial performance. While they found that inbound open innovation positively influenced financial performance, same was not found for outbound open innovation. Thus, inbound open innovation, proxy by 'the belief that it is good to use external sources to complement own R\&D' is assumed to significantly influence SMEs' performance.

$\mathbf{H}^{4}$ : Inbound open innovation has a significant influence on SMEs' performance

\section{Methodology Sample and data}

The data were obtained between January and March 2015, through a survey using a questionnaire similar to that of Community Innovation Survey 4, from the oil and gas firms in the upstream sub-sector of the petroleum sector. The survey sampled 150 indigenous oil and gas SMEs out of an average total of 178 firms that engage in production and servicing at the upstream sub-sector in the Nigerian petroleum industry. This was because of the inaccessibility of some of the firms physically and through their websites. This industry was chosen because it occupies a dominant position in Nigerian economy. Purposive sampling technique was adopted whereby SMEs with a number of employees between 10 and 199 were purposively selected in the industry, and a questionnaire was administered to the CEO or senior management staff in each of the firms for the purpose of eliciting information on the sources of open innovation and financial performance. The response rate for the administered questionnaire was $67.3 \%$.

\section{Measurements}

This study measured three major inbound open innovations. The dependent variable, which is SMEs' financial performance, was measured by asking the CEO or senior management staff to assess their firm's turnover. The performance level of a new product is usually measured as the degree to which a product performs well in the market compared to its major competitors in terms of turnover, profit and ROI (Kim, Im \& Slater 2013). The logarithm of financial turnover of the SMEs in the previous year was used as the proxy for SME performance (perf1) in this study. TS was measured by asking the respondents their extent of 'viewing external sources for ideas and knowledge (ts1)' and the extent to which they 'collect in-depth information about the industry (ts2)'. HTC was assessed by asking respondents the extent to which they 'cooperate with other firms (htc1)' and 'frequent networking with partners to jointly exchange knowledge and ideas (htc2)'. VTC was also measured by asking the respondents the extent to which they 'relate with their present and future customers (vtc1)', as well as 'the end-users (vtc2)' in supporting innovation. Direct inbound open innovation was also proxy by 'the belief that it is good to use external sources to complement own R\&D (oi1)'. Five-point Likert scale from 'not at all' (i.e. 1) to 'very high' (i.e. 5) extent was used to measure the aforementioned variables.

Three control variables were included in this study. These are size of technical staff, R\&D fund allocation and age of firm (Parida et al. 2012). Size of technical staff may influence innovation and performance of SMEs, as it is expected that firms with large number of technical staff may have larger relevant production skills (Adeyeye et al. 2013). R\&D fund allocation measured the amount apportioned to R\&D by the company using a scale in millions of naira. Age of the SME was measured by the number of years of establishment of the company from inception till the date of data collection. These control variables are expected to impact the SMEs' performance significantly.

\section{Methods}

The main method applied in this study is structural equation modelling (SEM). This method is used to test the relationships between the variables and to calculate the measurement errors in the hypotheses formulated. SEM is considered as an important quantitative technique for calculating and testing hypothesised models, describing relationships among a set of meaningful factors (Tripathy, Kumar Ray \& Sahu 2012). This method makes provision for performing multiple regression analysis on factors representing constructs of interest, hence facilitates combining factor analysis with multiple regression analysis (Yasin et al. 2009). The SEM is unique to other multivariate techniques, as it tests the sequential relationships between a series of independent and dependent variables (Hair et al. 2005), whereby one dependent variable could also be treated as independent variable in the subsequent analysis. SEM uses a method of maximum likelihood estimation. The method of maximum likelihood is a general statistical method for obtaining estimators.

The path diagram for the SEM constructed is shown in Figure 3. This shows that each of the TS, VTC and HTC has direct effect on SME performance, and also each of them has indirect effect through inbound open innovation on SME performance. Error term is captured by ' $e$ '. The significance and the extent of the impact of each of the factors are also 


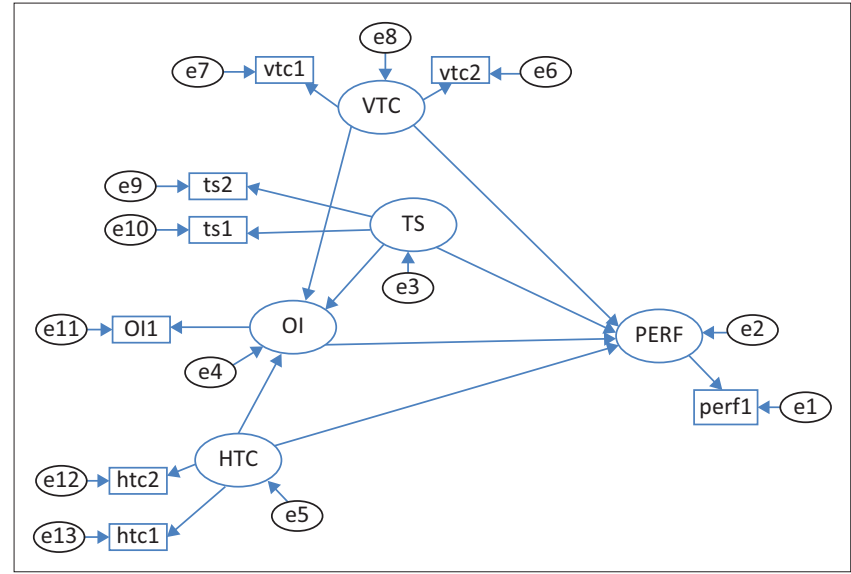

FIGURE 3: Path diagram of the structural equation modelling.

\begin{tabular}{llc} 
TABLE 1: Characteristics of the small and medium-sized enterprises. \\
\hline Firm's characteristics & Description & $\%$ \\
\hline Age of firm (in years) & Less than 5 & 9.2 \\
& $5-10$ & 16.3 \\
& $10-20$ & 21.4 \\
& $20-30$ & 49 \\
& Above 30 & 4.1 \\
& Total & 100 \\
Size of technical staff & $10-49$ & 11.2 \\
& $50-99$ & 50.0 \\
& $100-149$ & 17.3 \\
& $150-199$ & 21.5 \\
& Total & 100 \\
\hline R\&D fund allocation & Less than N500 000 & 2.0 \\
& N500 000 - N1 000 000 & 13.3 \\
& N1 000 000 - N2 000 000 & 22.4 \\
& N2 000 000 - N5 000 000 & 38.8 \\
& Above N5 000 000 & 23.5 \\
& Total & 100 \\
\hline
\end{tabular}

$R \& D$, research and development.

shown. While inbound open innovation serves as dependent variable at the first instance, it also serves as independent variable at subsequent instance in the structural model.

\section{Analysis and discussion of results Sample characteristics}

Table 1 shows that majority (96.9\%) of the SMEs started operation within the last 30 years. The result of the age of the SME might be because of the development of local content act and marginal field development initiatives by the Nigerian government in the late 1990s and early 2000s. Prior to this period, it was difficult for the SMEs to survive in the oil and gas sector as the multinational oil companies created a barrier to entry in terms of capital outlay, technology and human capital which made it difficult for small firms to venture into the industry. With the local content and marginal field initiatives of the Federal Government of Nigeria, these had encouraged the indigenous small players to also participate in the servicing, exploration and production of hydrocarbon in the sector. Size of technical staff of the SMEs was also shown in Table 1. Majority $(61.2 \%)$ of the SMEs had their technical staff size between 10 and 99, while the
TABLE 2: Correlation matrix.

\begin{tabular}{|c|c|c|c|c|c|c|c|c|}
\hline S. No. & Variables & 1 & 2 & 3 & 4 & 5 & 6 & 7 \\
\hline 1 & $\begin{array}{l}\text { SME } \\
\text { performance }\end{array}$ & 1 & - & - & - & - & - & - \\
\hline 2 & $\begin{array}{l}\text { Size of } \\
\text { technical staff }\end{array}$ & $0.31 *$ & 1 & - & - & - & - & - \\
\hline 3 & Age of SME & -0.27 & 0.13 & 1 & - & - & - & - \\
\hline 4 & $\begin{array}{l}\text { Fund } \\
\text { allocated to } \\
R \& D\end{array}$ & $0.48^{*}$ & $0.51^{* *}$ & -0.12 & 1 & - & - & - \\
\hline 5 & $\begin{array}{l}\text { Technology } \\
\text { scouting }\end{array}$ & $0.37^{* *}$ & $-0.14^{*}$ & -0.23 & 0.28 & 1 & - & - \\
\hline 6 & HTC & $0.53 * * *$ & 0.39 & 0.14 & $0.31 * *$ & 0.40 & 1 & - \\
\hline 7 & VTC & $0.62 * * *$ & 0.42 & 0.21 & $0.28 *$ & 0.32 & $0.38 *$ & 1 \\
\hline
\end{tabular}

remaining $38.8 \%$ of them had their number of technical staff between 100 and 199. The study also investigated the amount SMEs allocated or invested in R\&D in the preceding year, majority of them (61.2\%) asserted that they allocated between N1million (approximately \$5000) and N5million (approximately $\$ 25000$ ) to R\&D, while $23.5 \%$ of them allocated above N5million to R\&D.

\section{Impact of inbound open innovation on small and medium-sized enterprises' performance}

The data were first subjected to exploratory factor analysis with a view to know whether the variables are intercorrelated or not, and at the same time to reduce the number of the variables to the most meaningful ones. The Kaiser-MeyerOlkin (KMO) index of 0.712 indicates that the sample size is relatively adequate because the value is greater than 0.6 , and Bartlett's test of Sphericity is also significant at $p<0.001$ depicting that at least two of the variables are intercorrelated. Using Kaiser's criteria (eigenvalue $>1$ rule), four factors were extracted. The first and the largest factor explains $20.8 \%$ of the variance of the data and the cumulative percentage of the four factors explains $62.7 \%$ of the variance of the data. This shows that there is no problem of common method variance in the data, as only one singular factor does not explain the majority of the variance (Podsakoff \& Organ 1986; Wang et al. 2015). Table 2 shows the correlations of the variables. This reveals that HTC, VTC and TS are all positively and significantly correlated with SME performance at $5 \%$ level of significance. SME performance is also positively correlated with size of technical staff and fund allocated to R\&D but negatively correlated to age of SME. TS is also positively correlated with HTC, VTC and R\&D fund allocation but negatively correlated with size of technical staff and age of SME. Summarily, firm performance and the main sampled variables (TS, HTC and VTC) are positively correlated.

Having established the aforementioned statistics, SEM was conducted. AMOS was used to draw the path of the factors extracted. Table 3 shows the regression weights and the significance of the items extracted. The regression weights of all the factors are positive and also significant at $1 \%$ level of significance. The Cronbach's alpha values for TS, HTC and VTC are $0.79,0.76$ and 0.82 respectively. These indicate that the 
TABLE 3: Constructs and factors of the model.

\begin{tabular}{lll}
\hline Constructs and factors & $\begin{array}{l}\text { Cronbach's } \\
\text { alpha }\end{array}$ & $\begin{array}{l}\text { Standardised } \\
\text { regression weights }\end{array}$ \\
\hline $\begin{array}{l}\text { Technological scouting } \\
\text { ts1: View external source for idea and knowledge }\end{array}$ & - & - \\
$\begin{array}{l}\text { ts2: Collect in-depth information about the } \\
\text { industry }\end{array}$ & - & $0.62^{*}$ \\
Horizontal technology collaboration & 0.76 & - \\
$\begin{array}{l}\text { htc1: Cooperate with other competing and } \\
\text { non-competing firms }\end{array}$ & - & $0.53^{*}$ \\
$\begin{array}{l}\text { htc2: Frequent network with partners to } \\
\text { exchange knowledge and experience }\end{array}$ & - & $0.52^{*}$ \\
$\begin{array}{l}\text { Vertical technology collaboration } \\
\text { vtc1: Relating with present and future customers }\end{array}$ & - & - \\
$\begin{array}{l}\text { vtc2: Relating with end-users } \\
\text { Inbound open innovation }\end{array}$ & - & $0.73^{*}$ \\
$\begin{array}{l}\text { oi1: the belief that it is good to use external } \\
\text { sources to complement own R\&D }\end{array}$ & - & - \\
$\begin{array}{l}\text { Performance } \\
\begin{array}{l}\text { Perf1: financial turnover of the firm } \\
\hline\end{array}\end{array}$ & - & $0.68^{*}$ \\
\hline
\end{tabular}

R\&D, research and development.

$*, p<0.01$.

TABLE 4: Results of the hypothesis tests.

\begin{tabular}{lccl}
\hline Hypothesis & Direct (SR weights) & Indirect (SR weights) & Inferences \\
\hline $\mathrm{H}_{1}$ & $0.61 *$ & $0.63^{*}$ & Supported \\
$\mathrm{H}_{2}$ & $0.29 *$ & $0.51^{*}$ & Supported \\
$\mathrm{H}_{3}$ & $0.53^{*}$ & $0.60^{*}$ & Supported \\
$\mathrm{H}_{4}$ & $0.72 *$ & $\mathrm{~N} / \mathrm{A}$ & Supported \\
\hline $\mathrm{N} / \mathrm{A}$, not applicable; SR, standardised regression; $\mathrm{H}$, hypothesis. & \\
$*, p<0.01$. & & \\
& &
\end{tabular}

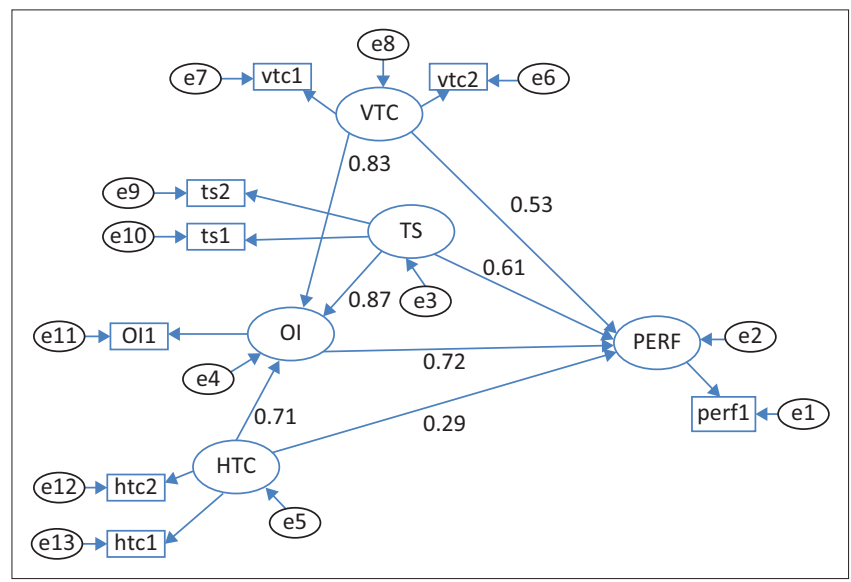

FIGURE 4: Structural equation modelling diagram showing the standardised regression weights of the paths.

factors which constitute each of the constructs are internally consistent and thus reliable as their values are above 0.7 .

Table 4 shows the result of the SEM conducted to test the four hypotheses formulated. Figure 4 shows the summary of the path diagram obtained in testing the hypotheses indicating the relationships among the factors. The causal direction is indicated by the arrows and the associated standardised regression weights. The level of significance for each regression weight is $p<0.001$.

The result shows that the regression weights of all the paths are positive and significant. This implies that all the hypotheses formulated are supported by the result of the models. TS has a positive and significant direct effect on SME performance with a standardised regression weight of 0.61 , and it also has positive and significant indirect effect through inbound open innovation on SME performance with a standardised regression weight of 0.63 . Also, HTC has positive and significant direct and indirect effects through inbound open innovation on SME performance with standardised regression weights of 0.29 and 0.51 respectively. More so, VTC with the standardised regression weights of 0.53 and 0.60 has significant direct and indirect effects respectively on SME performance. Meanwhile, inbound open innovation has a positive and significant direct effect on SME performance. The model fit tests are also conducted. The probability value of the Chi-square $\left(\chi^{2}\right)$ is 0.21 , which is above 0.05 , as expected, not to be significant; goodness of fit index is 0.94 , as expected, to be greater than 0.9 , normalised fit index is 0.88 , which is less than the expected value of 0.9 ; Tucker-Lewis index and comparative fit index are 0.91 and 0.92 respectively, all expected to be greater than 0.9 ; and root mean square error approximation is 0.02 , expected to be less than 0.05 . It could be inferred from the results that all the parameters, except normalised fit index, fit the model, and thus the model fits test is acceptable.

The outcomes of this model clearly show that TS, HTC and VTC are all important factors that contribute to inbound open innovation, and also positively and significantly contribute to financial performance of the SMEs in the Nigerian oil industry. The extent of HTC to the SME financial performance is relatively low, compared with other factors, as its regression weight is 0.29 . This indicates that the level of the SMEs' cooperation with other competing and non-competing firms, as well as network with partners to exchange ideas, is still relatively low. The findings suggest that TS, HTC and VTC can significantly improve the in-house innovation capabilities and the financial performance of the SMEs in oil and gas industry. This is in line with the studies of Parida et al. (2012), Wang et al. (2015) and Laursen and Salter (1996), among others. SMEs in Nigerian oil and gas industry should concert their efforts more on TS, HTC and VTC, so as to improve their financial performance and productivity.

It could also be deduced from the result of the correlations that the size of technical staff and fund allocated to R\&D should also be highly prioritised. That is, each SME should employ a large number of those that have requisite theoretical and practical knowledge or skill, as well as committing more funds to R\&D in order to boost their productivity. This will enable the internal capabilities to be developed for easy access to external knowledge and hence improve SMEs' financial performance.

The implication of this study is very important to the executive senior management of SMEs in the Nigerian oil and gas industry. The results reveal that external knowledge is an essential component which increases the financial performance of Nigerian SMEs in oil industry. Searching for new technology beyond the firm's boundary, will assist the management of the SMEs to improve the knowledge of the 
in-house technical staff that will bolster the turnover of the firms in the long run. Horizontal collaboration with other firms within and outside the industry can be favourable in the form of sharing important information about innovation and technology development. Furthermore, Christensen, Olesen and Kjær (2005) and Parida et al. (2012) asserted that if incremental innovation is the primary concern, it may be worthwhile for SMEs to initiate collaboration with other smaller firms, rather than larger firms during the initial stages of innovation development because of the flexibility and low risks associated with it. The SMEs can also collaborate with universities to broaden their knowledge base by jointly conducting research together. This will also enable them to get access to new forms of technological innovation that could assist their innovative activities which could increase their financial performance. Technology and innovation foresight about the industry can be very helpful to SMEs in the oil industry through vertical collaboration. This involves building a strong interaction with their customers and endusers. With these, SMEs will have access to current market information and trends that will assist them to plan ahead. Moreover, results from this study further revealed the significance of inbound open innovation in the Nigerian oil and gas SMEs. This study established that both HTCs and VTCs play an important role in internalising external knowledge towards reinforcing in-house innovation processes to improve the SMEs' financial performance.

\section{Conclusion}

This study has been able to show that inbound open innovation is crucial to SME performance in the Nigerian oil and gas industry. A SEM was adopted and the results indicate that TS, VTC and HTC all contribute to inbound open innovation, which then have a positive and significant influence on the financial performance of SMEs. The management members of each SME should continually consider collaboration with the external actors because they cannot singularly possess all the innovative skills required in the industry. Also, each firm should commit itself to allocate more funds to $R \& D$, and at the same time should hire those that have relevant production skills in their firms. The competences of existing members of staff should also be developed, so as to set them ready to absorb any external technology entering their firm. Getting the right technological partner helps the SMEs to strengthen their innovation capabilities, which leads to a high financial performance in terms of turnover and profit.

\section{Limitation of the study}

The study concentrates on inbound open innovation among the SMEs in the oil industry leaving the outbound innovation and larger firms out of the model.

\section{Acknowledgements}

I acknowledge Prof. Akinbami, Prof. Akarakiri and Mrs F.O. Akinwale at Obafemi Awolowo University, Nigeria, as well as the Editor and the anonymous reviewers for their constructive critique(s) to make the article better.

\section{References}

Adelowo, C., Akinwale, Y. \& Olaopa, O., 2017, 'Innovation and knowledge transfer in Nigeria', International Journal of Research, Innovation and Commercialisation 1(1), 57-73. https://doi.org/10.1504/IJRIC.2017.082298

Adeyeye, A., Jegede, O. \& Akinwale, Y., 2013, 'The impact of technology innovation and R\&D on firms' performance: An empirical analysis of Nigeria's service sector', International Journal of Technological Learning, Innovation and Development 6(4), 374-395.

Adeyeye, A., Jegede, O., Oluwadare, A. \& Aremu, F., 2016, 'Micro-level determinants of innovation: Analysis of the Nigerian manufacturing sector', Innovation and Development 6(1), 1-14. https://doi.org/10.1080/2157930X.2015.1047110

Ahn, J., Minshall, T. \& Mortara, L., 2015, 'Open innovation: A new classification and its impact on firm performance in innovative SMEs', Journal of Innovation Management 3(2), 33-54.

Aigboduwa, J. \& Oisamoje, M., 2013, 'Promoting small and medium enterprises in the Nigerian oil and gas industry', European Scientific Journal 9(1), 244-261.

Akinwale, Y., 2016, 'Harnessing science technology and innovation for enhancing marginal oil and gas field development in Nigeria: A comparative analysis', International Journal of e-Business and e-Government Studies 8(2), 43-67.

Akinwale, Y., Adepoju, A. \& Olomu, M., 2017, 'The impact of technological innovation on SMEs profitability in Nigeria', International Journal of Research, Innovation and Commercialization 1(1), 74-92. https://doi.org/10.1504/IJRIC.2017.082299

Akinwale, Y., Dada, A., Oluwadare, A., Jesuleye, O. \& Siyanbola, W., 2012, 'Understanding the nexus of R\&D, innovation and economic growth in Nigeria', International Business Research 5(11), 187-196. https://doi.org/10.5539/ibr.v5n11p187

Ariweriokuma, S., 2009, The political economy of oil and gas in Africa: The case of Nigeria, Routledge, New York.

Bianchi, M., Orto, S., Frattini, F. \& Vercesi, P. 2010, 'Enabling open innovation in smalland medium-sized enterprises: How to find alternative applications for your technologies', $R$ and D Management 40(4), 414-430.

Bosworth, B. \& Collins, S., 2003, 'The empirics of growth: An update', Brookings Panel on Economic Activity 10(2), 113-206. https://doi.org/10.1353/eca.2004.0002

Brunswicker, S. \& Vanhaverbeke, W., 2014, 'Open innovation in small and mediumsized enterprises (SMEs): External knowledge sourcing strategies and internal organizational facilitators', Journal of Small Business Management 53(4), 1241-1263.

Central Bank of Nigeria, 2015, Statistical Bulletin, Abuja, Nigeria.

Chesbrough, H., 2003a, Open innovation: The new imperative for creating and profiting from technology, Harvard Business Press, Boston, MA.

Chesbrough, H., 2003b, 'The era of open innovation', MIT Sloan Management Review 44(3), 35-41.

Chesbrough, H., 2006, Open business models: How to thrive in the new innovation landscape, Harvard Business School Press, Boston, MA.

Chesbrough, H. \& Bogers, M., 2014, 'Explicating open innovation: Clarifying an emerging paradigm for understanding innovation', in $H$. Chesbrough, $W$. Vanhaverbeke \& J. West (eds.), New frontiers in open innovation, pp. 3-28, Oxford University Press, Oxford, UK.

Chesbrough, H. \& Crowther, A., 2006, 'Beyond high tech: Early adopters of open innovation in other industries', Research and Development Management 36(3), 229-236. https://doi.org/10.1111/j.1467-9310.2006.00428.x

Chesbrough, H., Vanhaverbeke, W. \& West, J., 2006, Open innovation: Researching a new paradigm, Oxford University Press, New York.

Christensen, J., Olesen, M. \& Kjær, J., 2005, 'The industrial dynamics of open innovation: Evidence from the transformation of consumer electronics', Research Policy 34(10), 1553-1549. https://doi.org/10.1016/j.respol.2005.07.002

Colombo, M., Piva, E. \& Rossi-Lamastra, C., 2014, 'Open innovation and within-industry diversification in small and medium enterprises: The case of open source software firms', Research Policy 43, 891-902. https://doi.org/10.1016/j.respol.2013.08.015

Dahlander, L. \& Gann, D., 2010, 'How open is innovation?', Research Policy 39, 699709. https://doi.org/10.1016/j.respol.2010.01.013

Egbetokun, A., Adeniyi, A. \& Siyanbola, W., 2012, 'On the capability of SMEs to innovate: The cable and wire manufacturing subsector in Nigeria', Internationa Journal of Learning and Intellectual Capital 9(1/2), 64-85. https://doi. org/10.1504/IJLIC.2012.043981

Gault, F., 2010, Innovation strategies for a global economy: Development, implementation, measurement and management, Edward Elgar, Northampton, MA.

Hair, J.F., Jr., Anderson, R.E., Tatham, R.L. \& Black, W.C., 2005, Multivariate data analysis, 5th edn., second Indian reprint, Pearson Education, Inc., New Delhi, India.

Henkel, J., 2006, 'Selective revealing in open innovation processes: The case of embedded Linux', Research Policy 35(7), 953-969. https://doi.org/10.1016/j. respol.2006.04.010

Hippel, E., 2005, Democratizing innovation, MIT Press, Cambridge, MA.

Huizingh, E., 2011, 'Open innovation: State of the art and future perspectives', Technovation 31(1), 2-9. https://doi.org/10.1016/j.technovation.2010.10.002

Hung, K. \& Chou, C., 2013, 'The impact of open innovation on firm performance: The moderating effects of internal R\&D and environmental turbulence', Technovation 33, 368-380. https://doi.org/10.1016/j.technovation.2013.06.006

Ismail, K., Omar, W., Soehod, K., Senin, A. \& Akhtar, S., 2014, Role of innovation in SMEs performance: A case of Malaysian SMEs, viewed 02 April 2016, from http://www. europment.org/library/2014/prague/bypaper/AMCME-EBA/AMCME-EBA-23.pdf 
Kasseeah, H., 2013, 'Innovation and performance in small- and medium-sized enterprises: Evidence from Mauritius', Innovation and Development 3(2), 259275. https://doi.org/10.1080/2157930X.2013.825069

Kaufmann, A. \& Tödtling, F., 2002, 'How effective is innovation support for SMEs? An analysis of the region of Upper Austria', Technovation 22(3), 147-159. https://doi. org/10.1016/S0166-4972(00)00081-X

Kim, H. \& Park, Y., 2010, 'The effects of open innovation activity on performance of SMEs: The case of Korea', International Journal of Technology Management 52(34), 236-256. https://doi.org/10.1504/IJTM.2010.035975

Kim, J., 2011, 'The economic growth effect of R\&D activity in Korea', Korea and the World Economy Journal 12(1), 25-44.

Kim, N., Im, S. \& Slater, S., 2013, 'Impact of knowledge type and strategic orientation on new product creativity and advantage in high-technology firms', Journal of Product Innovation Management 30(1), 136-153. https://doi.org/10.1111/ j.1540-5885.2012.00992.x

Koput, K., 1997, 'A chaotic model of innovative search: Some answers, many questions', Organization Science 8(5), 528-542.

Laursen, K. \& Salter, A., 2006, 'Open for innovation: The role of openness in explaining innovation performance among UK manufacturing firms', Strategic Management Journal 27(2), 131-150. https://doi.org/10.1002/smj.507

Lee, S., Park, G., Yoon, B. \& Park, J., 2010, ‘Open innovation in SMEs - An intermediated network model', Research Policy 39, 290-300. https://doi.org/10.1016/j. respol.2009.12.009

Lichtenthaler, U., 2009, 'Absorptive capacity, environmental turbulence, and the complementarity of organizational learning processes', Academy of Management Journal 52(4), 822-846. https://doi.org/10.5465/AMJ.2009.43670902

Lukas, B. \& Ferrell, O., 2000, 'The effect of market orientation on product innovation', Journal of the Academy of Marketing Science 28(2), 239-247. https://doi. org/10.1177/0092070300282005

Mytelka, L., 2000, 'Local systems of innovation in a globalized world economy', Industry and Innovation 7(1), 33-54. https://doi.org/10.1080/713670244

National Bureau of Statistics (NBS), 2015, Micro, Small and Medium Enterprise National Survey, Federal Republic of Nigeria, Abuja.

National Science Foundation, 2006, 'Science resource studies', in Survey of industria research development, Census Bureau, USA.

Olomu, M., Akinwale, Y. \& Adepoju, A., 2016, 'Harnessing technological and nontechnological innovations for SMEs profitability in the Nigerian Manufacturing Sector', American Journal of Business, Economics and management 4(4), 75-88.

Parida, V., Westerberg, M. \& Frishammar, J., 2012, 'Inbound open innovation activities in high-tech SMEs: The impact on innovation performance', Journal of Small Business Management 50(2), 283-309.

Pittaway, L., Robertson, M., Munir, K., Denyer, D. \& Neely, A., 2004, 'Networking and innovation: A systematic review of the evidence', International Journal of Management Reviews 5(3), 137-168.
Podsakoff, P. \& Organ, D., 1986, 'Self-reports in organizational research: Problems and prospects', Journal of Management 12(4), 531-544. https://doi.org/10.1177/ prospects', Journal of

Qian, G. \& Li, L., 2003, 'Profitability of small- and medium-sized enterprises in hightech industries: The case of the biotechnology industry', Strategic Management Journal 24(9), 881-887.

Rothwell, R. \& Dodgson, M., 1994, 'Innovation and size of firm', in M. Dodgson (ed.), Handbook of industrial innovation, pp. 310-324, Edward Elgar von, Aldershot.

Siyanbola, W., Oladipo, O., Oyewale, A., Famurewa, A. \& Ogundari, I., 2012, 'Academiaindustry interactions in Nigeria pharmaceutical innovation system', Procedia-Social and Behavioral Sciences 52, 279-289. https://doi.org/10.1016/j.sbspro.2012.09.465

Small and Medium Enterprises Development Agency of Nigeria (SMEDAN), 2015 Survey report on small and medium enterprises (SMEs) in Nigeria, National SME Collaborative Survey between National Bureau of Statistics (NBS) and the Smal and Medium Enterprises Development Agency of Nigeria (SMEDAN), Federal Republic of Nigeria, Abuja.

SMEDAN \& National Bureau of Statistics (NBS), 2013, Collaborative surveys: Selected findings, viewed 20 August 2017, from https://www.smedan.gov.ng/images/ PDF/2013-MSME-Survey-Summary-Report.pdf

Spithoven, A., Clarysse, B. \& Knockaert, M., 2010, 'Building absorptive capacity to organise inbound open innovation in traditional industries', Technovation 30(2), 130-141. https://doi.org/10.1016/j.technovation.2009.08.004

Teece, D., 1996, 'Firm organization, industrial structure, and technological innovation', Journal of Economic Behavior and Organization 31(2), 193-224. https://doi. org/10.1016/S0167-2681(96)00895-5

The Nigeria economic recovery \& growth plan 2017-2020 report, 2017, ERGP'S Top Execution Priorities, viewed 20 August 2017, from https://www.smedan.gov.ng/ images/NECR.pdf

Tripathy, S., Kumar Ray, P. \& Sahu, S., 2012, 'Factors governing R\&D practices in Indian manufacturing firms: Structural equation modelling', International Journal of Modelling in Operation Management 2(1), 45-68. https://doi.org/10.1504/ IJMOM.2012.043960

Van de Vrande, V., de Jong, J., Vanhaverbeke, W. \& de Rochemont, M., 2009, 'Open innovation in SME's: Trends, motives and management challenges', Technovation 29(6-7), 423-437. https://doi.org/10.1016/j.technovation.2008.10.001

Waheed, A., 2012, 'Innovation determinants and innovation as a determinant: Evidence from developing countries', PhD dissertation, UNU-MERIT, Maastricht University.

Wang, C., Chang, C. \& Shen, G., 2015, 'The effect of inbound open innovation on firm performance: Evidence from high-tech industry', Technological Forecasting \& Social Change 99, 222-230. https://doi.org/10.1016/j. techfore.2015.07.006

Yasin, M., Augusto, M., Alavi, J. \& Lisboa, J., 2009, 'A SEM approach to assessing the effectiveness of quality improvement initiatives in service organisations: A systematic perspective', International Journal of Business and Systems Research 3(3), 372-386. https://doi.org/10.1504/IJBSR.2009.026189 